\title{
ТЕОРЕТИКО-МЕТОДИЧНІ АСПЕКТИ
} ФІЗИЧНОГО ВИХОВАННЯ І СПОРТУ

\author{
DOI: $10.26693 / j m b s 06.05 .465$ \\ UDC 613.72:373.3.09]=111 \\ Zerf Mohammed, Abdelkader Guebli, Mohamed Hadjar Kherfane

\section{Influence of Frequency and Time Implications} \\ on Efficacy of Primary School Active Break Programs
}

\author{
Abdel Hamid Ibn Badis University Mostaganem Institute of Physical Education and Sports, \\ Mostaganem, Algeria
}

Classroom-based physical activity breaks are suggested to positively impact children's attention during their school day. Frequency and time implications are important as decisive factors in structuring primary school active break programs.

The purpose of the study was to research the influence of frequency and time implications on efficacy of primary school active break programs.

Materials and methods. This academic survey was admitted as the first Algerian pilot research among primary schools. Its appointment aims are to test the effect of frequency and time implications as decisive factors in structuring primary school active break programs.

4 teachers and 5-grade class levels took part in the study. A total of 180 children (100 girls and 80 boys), 45 in each class were involved in the study. The average age of the participants was $10.4 \pm 0.61$ years old. All participants provided their written consent to attend the study. The ethics committee of Physical Education Institute, University of Abdel Hamid Ibn Badis Mostaganem had also given its approval.

All children were divided in four groups. Group 1 (20 boys and 25 girls) had 2 minutes of exercise every 20 minutes of siting. Group 2 (19 boys and 26 girls) had 6 minutes of exercise for every 1 -hour of sitting. Group 3 (19 boys and 26 girls) had 9-minute traditional Active Breaks Classroom-Based Physical Activity program integrated within regular day school break periods. Group 4 was a control one with no Active Breaks Classroom-Based Physical Activity program. All teachers, who voluntarily accepted to be engaged in this experience, were asked to apply the video-based physical activity appropriate for their students according to the model and content (time-frequency) and they encouraged their students to replicate their daily base-physical-activity as proposed.
Push, pull, squat, standing chair single-leg balance, flexibility, self-myofascial release and static stretching were used as a complimentary physical activity program.

Results and discussion. This study focuses on three frequencies and time implications of proposed Active Break Physical Classroom Routine. The test confirmed the benefits of active breaks program in groups. The higher scores than in the control group were recorded in the post-tests. This study explains it by the complementary time practised by experimental groups according to Active Breaks Classroom-Based Physical Activity program. Clear significant inverse correlations were established between the active-standing time involved and classroom inactive time chair sitting.

Conclusion. The results of the study confirmed that it is more useful to use the short break program no longer than 5 minutes, frequently repeated with 2 minutes, after every 20 minutes of prolonged static setting. It has to be used as the prominent strategy for structuring the feasible and potential efficacy of primary school Active Break Program. This model is able to decrease sedentary time and increase daily energy expenditure.

Keywords: primary schools, children, physical activity, exercise time and frequency, active break program.

Introduction. Research approves Active Breaks Classroom-Based Physical Activity programs (ABCPA) as a time-efficient, feasible and appealing approach. However, some minor modifications in terms of the required frequency and intensity of Active Breaks Classroom-Based Physical Activity programs are requested to improve fidelity [1].

In this study the time interventions were advocated. In some studies it was subjected to integrate at 
least two 20-min moderate-intensity active breaks a day or 10 to 20 -min active breaks as effective time implication, not 5-min active breaks [2, 3]. Dining during other lessons longer than $5 \mathrm{~min}$, claimed by their teachers to be not feasible within a crowded curriculum $[4,5]$.

Further research will claim to develop more feasible active breaks programs $[6,7]$.

Aims in the present investigation were three proposed Active Breaks Classroom-Based Physical Activity programs (ABC-PA). There was a challenge toward four-week. Push, pull, squat, standing chair single-leg balance, flexibility, self-myofascial release and static stretching were used as a complimentary PA program (Cooper Institute for Aerobics Research, 2017) [8]. It is recommended by the National Academy of Sports Medicine as easy workouts that involve only 2-4 sets or higher repetition schemes (12-20 repetitions) [9]. It was implicated in this study under the above ABC-PA models.

Group 1 applied the Model (ABC-PA-20-min) of $5 \mathrm{~min}$, practising after every $20 \mathrm{~min}$ of static sitting and group 2 applied the Model of 6 min ABC-PA (1h), using it after every one-hour studying, group 3 applied additional to Model $10 \mathrm{~min}$ ABC-PA implicated via regular classroom breaks. Figure 1 shows a program and Table 2 shows ABC-PA models and time-frequency repetitions protocol, which are practised in the present study.

To judge their effectiveness, their results were compared with a control group with no ABC-PA. Fitness-Gram battery was used as a comprehensive assessment of school health policies and public health applications (Cooper Institute for Aerobics Research, 2017). It was elaborated by the Cooper Institute and includes five components of health-related fitness: aerobic endurance, muscular strength and muscular endurance, flexibility, and body composition. They were calculated based on health-fitness standards designed according to the age and gender, designed to promote physical activity with the vision of improving the efficiency and effectiveness of school-based physical education [10].

The most comprehensive test battery practises are used in this study as in many educational systems of different countries to prevent the non-communicable diseases arising from an unhealthy lifestyle [11]. They are applied in the present to determine the effect of frequency and time implications on ABC-PA efficiency, such as sufficient bodily activity with more adequate energy expenditure and adjustments of sitting time in the classroom [12].

The purpose of the study was to research the influence of frequency and time implications on efficacy of primary school active break programs.

Materials and methods of research. This academic survey was admitted as the first Algerian pilot research among primary schools. Its appointment aims are to test the effect of frequency and time implications as decisive factors in structuring primary school active break programs (ABC-PA).

Hypothesis in this study is based on 3 proposals of ABC-PA, one is short, 5 min and two - longer than $5 \mathrm{~min}$. These programs were applied in this study by three groups during four weeks using video-based physical activity for the academic years (2017-2018). Figure 1 shows the program and Table 2 presents ABC-PA models and time-frequency repetitions protocol practises in the present study.

All teachers, who voluntarily accepted to be engaged in this experience, were asked to apply the video-based physical activity appropriate for their students according to the model and content (time-frequency) and they encouraged their students to replicate their daily base-physical-activity as proposed.

Participants. The samples included 4 teachers and 5-grade class levels. A total of 180 children (100 girls and 80 boys), 45 in each class were involved in the study. All participants provided their written consent to attend the study. Their characteristics before experimentation beginning, are shown in Table 1. The ethics committee of Physical Education Institute, University of Abdel Hamid Ibn Badis
Table 1 - Present characteristics of samples in the pre-test

\begin{tabular}{|c|c|c|c|c|c|}
\hline Variables & $\begin{array}{c}\text { Total } \\
n=180\end{array}$ & $\begin{array}{c}\text { Group } 1 \\
n=45\end{array}$ & $\begin{array}{c}\text { Group } 2 \\
n=45\end{array}$ & $\begin{array}{c}\text { Group } 3 \\
n=45\end{array}$ & $\begin{array}{c}\text { Group } 4 \\
n=45\end{array}$ \\
\hline Age (years) & $10.4 \pm 0.61$ & $10.1 \pm 0.92$ & $10.5 \pm 0.48$ & $10.61 \pm 0.46$ & $10.22 \pm 0.80$ \\
\hline$F$ at $p \leq 0.05$ & \multicolumn{5}{|c|}{$F=78.55, p=0.21$} \\
\hline B.H (cm) & $143 \pm 5.22$ & $144.2 \pm 4.79$ & $143.5 \pm 4.56$ & $144 \pm 3.55$ & $143.83 \pm 2.99$ \\
\hline$F$ at $p \leq 0.05$ & \multicolumn{5}{|c|}{$F=120.58, p=0.32$} \\
\hline B.W (kg) & $36.52 \pm 4.82$ & $36.48 \pm 4.62$ & $37.9 \pm 3.37$ & $36.88 \pm 5.02$ & $36.75 \pm 3.75$ \\
\hline$F$ at $p \leq 0.05$ & \multicolumn{5}{|c|}{$F=550, p=0.45$} \\
\hline Male & 80 & 20 & 19 & 19 & 22 \\
\hline$F$ at $p \leq 0.05$ & \multicolumn{5}{|c|}{$F=74.89, p=0.58$} \\
\hline Female & 100 & 25 & 26 & 26 & 23 \\
\hline$F$ at $p \leq 0.05$ & \multicolumn{5}{|c|}{$F=94.45, p=0.22$} \\
\hline Grade level & \multicolumn{5}{|c|}{ All class 5 grade level } \\
\hline
\end{tabular}

Notes: Group 1 with ABC-PA (20min) is the model group with 2 min ABC-PA for every 20 min classroom setting. Group 2 with ABC-PA (1h) is the model group with 6 min ABC-PA at every 54 min classroom setting. Group 3 with ABC-PA (10min) is the model group with 9 min traditional ABC-PA integrated within regular day school break periods. Group 4 was a control one with no ABC-PA. ANOVA One-Way Test (p). 
Mostaganem had also given its approval under the code '45/IEPS/2017'.

Test Items and Materials. The test battery consisted of the Fitness Gram battery test. It was recently identified as a significant battery to assess health-related fitness, recorded from the personal aerobic capacity (VO2max) accomplishments, body composition (BMI), muscular strength (upper body-M.S.U.B-and lower body-M.S.L.B), abdominal endurance (E.A) and flexibility (F. L. B).

- Aerobic capacity (VO2max). We based on the reduced Cooper test. The child runs or walks around a marked rectangle measuring $9 \times 18 \mathrm{~m}$ (the size of a volleyball field) for 6 minutes. Both running and walking are allowed. The test item score is the distance traversed in 6 minutes (measured in meters).

- Body Composition (BMI). We based on body mass index (calculated from height and weight).

- Muscular strength of upper and lower body, abdominal endurance and flexed trunk:

- Muscular strength of the upper body (M.S.U.B). We based on pushing a medicine ball $(1 \mathrm{~kg})$ with two hands as far as possible. The starting position is with the feet parallel to each other and shoulder-width apart, with the ball held against the chest. Test item score (better of two attempts) is the distance achieved (measured in meters).

- Muscular strength of the lower body (M.S.L.B). We based on the vertical jump test. The student jumped vertically as high as possible, using both arms and legs to assist in projecting the body upwards.

- Flexibility (F. L. B). We based on tests "sit and reach" to measure lower back and hamstring muscle flexibility. The score is recorded to the nearest centimetre or half-inch as the distance is reached by the hand.

- Abdominal Endurance (E.A). We based on Abdominal Curl-Sit Up endurance tests typically conducted over one minute and measure the maximum number of correctly performed sit-ups in that time.

Procedure. All samples were educated and evaluated individually. Each test item was clarified and demonstrated before the child started. The tests were taken before and after the realisations of the active break programs proposed for each sample. Practice by experimental groups was prepared based on video exercises. Table 2 shows the model time of repetitions and total sending voluntary time and Figure 1 shows the content and Figure 2 the frequently complimentary time blew ABC-PA modalities proposed. For the progress of participants, we based on Max's child repetitions to improve cardiopulmonary fitness and reduce their sitting static at desks [11].
Table 2 - Present ABC-PA models and time-frequency repetitions protocol practises in the present study

\begin{tabular}{|c|c|c|c|}
\hline Model & $\begin{array}{c}\text { Time } \\
\text { implication }\end{array}$ & $\begin{array}{c}\text { Frequen- } \\
\text { cy(F) }\end{array}$ & $\begin{array}{c}\text { Total per day } \\
\text { program rep- } \\
\text { etitions }\end{array}$ \\
\hline $\begin{array}{c}\text { ABC-PA } \\
(20 \text { min })\end{array}$ & $\begin{array}{c}2 \text { minutes for } \\
\text { every 20 min- } \\
\text { utes of sitting }\end{array}$ & $\begin{array}{c}2 \mathrm{~min}^{*} 3 \text { by } \\
\text { one hour }\end{array}$ & 36 \\
\hline $\begin{array}{c}\text { ABC-PA } \\
(1 \mathrm{~h})\end{array}$ & $\begin{array}{c}6 \text { min for } \\
\text { every 1-hour } \\
\text { of sitting }\end{array}$ & $\begin{array}{c}6 \mathrm{~min}^{*} 1 \text { by } \\
\text { one hour }\end{array}$ & 36 \\
\hline $\begin{array}{c}\text { ABC-PA } \\
(10 \mathrm{~min})\end{array}$ & $\begin{array}{c}\text { Break recrea- } \\
\text { tion periods }\end{array}$ & $9 \mathrm{~min}^{* 1}$ & 20 \\
\hline
\end{tabular}

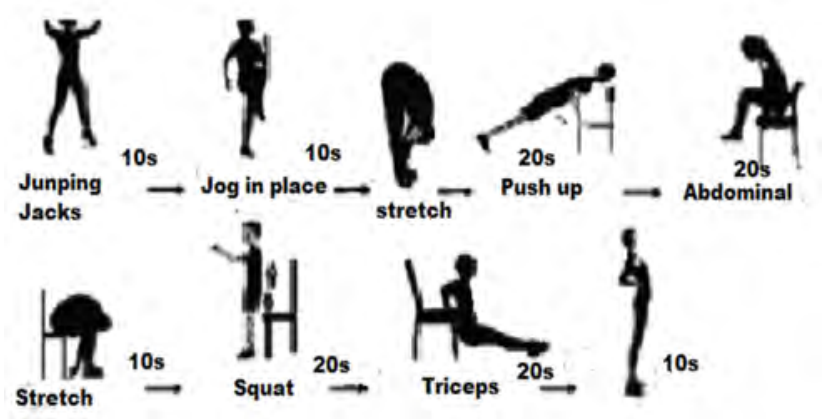

Figure 1 - Present content of ABC-PA program

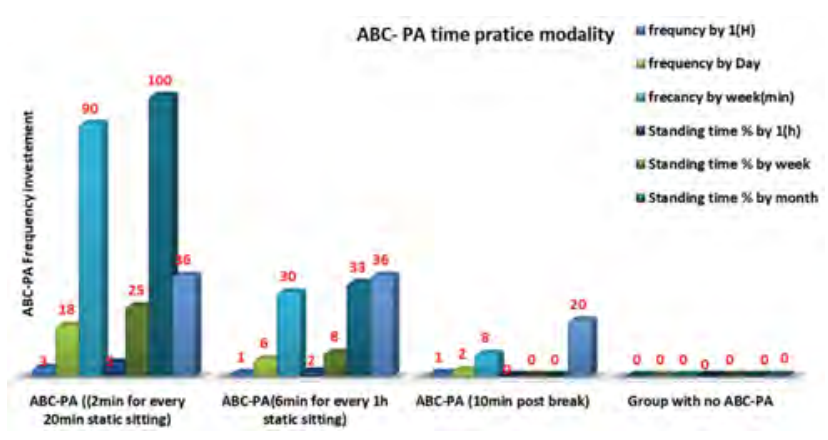

Figure 2 - Present frequently complimentary time blew ABC-PA modalities proposed

Data Analysis. The collected data were tabulated and statistically analysed using IBM SPSS Statistics 16.01 (Armonk, NY, USA). Arithmetic average (X), standard deviation (SD), person correlations ( $\mathrm{r}$ ), ANOVA One-Way and LSD were computed as the sample's entire multiple comparison tests [13]. The results were considered significant at $p 0.05$.

Results. Our samples are homogeneous in all pre-test in Tables 1 and 3 . It is support by the insignificance of ANOVA one way in the pre-test. The inverse of post-test records for the advantage of active break programs were compared to control group results.

Fitness Gram battery test confirmed the benefits of active breaks program in groups. The higher scores than in the control group were recorded in the posttests. This study explains it by the complementary time practised by experimental groups according to $A B C-P A$ and it is enumerated in Figure 1-2 and Tables 3-4. Clear significant inverse correlations were 
Table 3 - Present pre- and post-test physical fitness samples results

\begin{tabular}{|c|c|c|c|c|c|c|}
\hline \multicolumn{3}{|c|}{ Variables } & Group1 & Group2 & Group3 & Group4 \\
\hline \multirow{2}{*}{ VO2max } & Pre-test & \multirow{2}{*}{$\mathrm{X} \pm \mathrm{SD}$} & $42.28 \pm 4.55$ & $43.49 \pm 4.78$ & $42.55 \pm 7.22$ & $43.24 \pm 5.22$ \\
\hline & Post-test & & $44.98 \pm 2.32$ & $44.69 \pm 3.03$ & $44.55 \pm 2.46$ & $42.94 \pm 1.67$ \\
\hline \multirow{2}{*}{$F$ at $p \leq 0.05$} & Pre-test & \multicolumn{5}{|c|}{$F=54.22, p=0.43$} \\
\hline & Post-Test & \multicolumn{5}{|c|}{$F=6.04, p=0.00$} \\
\hline \multirow{2}{*}{ BMI } & Pre-test & \multirow{2}{*}{$\mathrm{X} \pm \mathrm{SD}$} & $22.55 \pm 1.55$ & $21.88 \pm 2.45$ & $22.23 \pm 1.85$ & $22.44 \pm 1.47$ \\
\hline & Post-test & & $21.32 \pm 1.88$ & $21.48 \pm 1.44$ & $21.51 \pm 2.82$ & $22.65 \pm 3.09$ \\
\hline \multirow{2}{*}{$F$ at $p \leq 0.05$} & Pre-test & \multicolumn{5}{|c|}{$F=19.22, p=0.64$} \\
\hline & Post-Test & \multicolumn{5}{|c|}{$F=7.46, p=0.00$} \\
\hline \multirow{2}{*}{ M.S.U. B } & Pre-test & \multirow{2}{*}{$\mathrm{X} \pm \mathrm{SD}$} & $2.42 \pm 2.35$ & $2.44 \pm 3.42$ & $2.34 \pm 2.52$ & $2.40 \pm 3.42$ \\
\hline & Post-test & & $2.94 \pm 1.35$ & $2.78 \pm 1.42$ & $2.66 \pm 1.02$ & $2.40 \pm 1.42$ \\
\hline \multirow{2}{*}{$F$ at $p \leq 0.05$} & Pre-test & \multicolumn{5}{|c|}{$F=22, p=0.46$} \\
\hline & Post-Test & \multicolumn{5}{|c|}{$F=7.26, p=0.00$} \\
\hline \multirow{2}{*}{ M.S.L. B } & Pre-test & \multirow{2}{*}{$\mathrm{X} \pm \mathrm{SD}$} & $11.92 \pm 2.55$ & $11.81 \pm 3.02$ & $11.74 \pm 2.52$ & $11.78 \pm 3.22$ \\
\hline & Post-test & & $15.75 \pm 2.03$ & $14.52 \pm 2.17$ & $14.08 \pm 2.19$ & $12.09 \pm 2.08$ \\
\hline \multirow{2}{*}{$F$ at $p \leq 0.05$} & Pre-test & \multicolumn{5}{|c|}{$F=75, p=0.41$} \\
\hline & Post-Test & \multicolumn{5}{|c|}{$F=8.26, p=0.00$} \\
\hline \multirow{2}{*}{ E. A } & Pre-test & \multirow{2}{*}{$\mathrm{X} \pm \mathrm{SD}$} & $8.88 \pm 3.33$ & $7.89 \pm 2.98$ & $8.22 \pm 5.45$ & $7.98 \pm 4.22$ \\
\hline & Post-test & & $14.58 \pm 5.48$ & $13.99 \pm 2.78$ & $13.75 \pm 4.84$ & $9.02 \pm 3.43$ \\
\hline \multirow{2}{*}{$F$ at $p \leq 0.05$} & Pre-test & \multicolumn{5}{|c|}{$F=12.2, p=0.56$} \\
\hline & Post-Test & \multicolumn{5}{|c|}{$F=7.27, p=0.00$} \\
\hline \multirow{2}{*}{ F. L. B } & Pre-test & \multirow{2}{*}{$\mathrm{X} \pm \mathrm{SD}$} & $14.55 \pm 2.58$ & $13.99 \pm 2.78$ & $14.37 \pm 4.88$ & $14.72 \pm 3.42$ \\
\hline & Post-Test & & $17.05 \pm 1.45$ & $16.09 \pm 1.65$ & $15.25 \pm 2.09$ & $14.04 \pm 1.52$ \\
\hline \multirow{2}{*}{$F$ at $p \leq 0.05$} & Pre-test & \multicolumn{5}{|c|}{$F=122, p=0.85$} \\
\hline & Post-Test & \multicolumn{5}{|c|}{$F=6.48, p=0.00$} \\
\hline
\end{tabular}

Notes: Body Composition (BMI)/Muscular strength Upper body (M.S.U.B)/Muscular strength lower body (M.S.L.B)/Flexibility (F. I. B)/Endurance Abdominal (E.A), Arithmetic Average (X), Standard Deviation (SD), ANOVA One-Way Test (p).

Table 4 - Multiple Comparisons built on the models used and the voluntary time standing implied

\begin{tabular}{|c|c|c|c|c|}
\hline $\begin{array}{c}\text { Dependent } \\
\text { Variable }\end{array}$ & (I) & (J) & $\begin{array}{c}\text { Mean } \\
\text { Difference } \\
(\mathrm{I}-\mathrm{J})\end{array}$ & $P \leq 0.05$ \\
\hline \multirow{3}{*}{ Daily } & \multirow{3}{*}{ Group1 } & Group2 & $4.22^{* \star}$ & 0.00 \\
\hline & & Group3 & $6.78^{* \star}$ & 0.00 \\
\hline & & Group4 & $8.38^{* *}$ & 0.00 \\
\hline \multirow{3}{*}{ Week } & \multirow{3}{*}{ Group1 } & Group2 & $4.04^{* *}$ & 0.00 \\
\hline & & Group3 & $5.18^{* *}$ & 0.00 \\
\hline & & Group4 & $7.58^{* *}$ & 0.00 \\
\hline \multirow{3}{*}{ Month } & \multirow{3}{*}{ Group1 } & Group2 & $4.32^{* *}$ & 0.00 \\
\hline & & Group3 & $5.45^{\star *}$ & 0.00 \\
\hline & & Group4 & $7.98^{* *}$ & 0.00 \\
\hline
\end{tabular}

Note: *The mean difference ( $p$, ANOVA One-Way Test) is significant at the 0.05 level.

established between the active-standing time involved and classroom inactive time chair sitting, which is outlined in Table 5. Although based on LSD post-test, all multiple comparisons calculated are in the interest of ABC-PA (20 min). The efficacy of time implications and frequencies per day were recorded to promote the sufficient levels of physical activity to achieve adequate energy expenditure with significance de- manded by standing desk at the everyday classroom compared with model of one-hour and recreational breaks periods. Frequencies compared to other models were outlined in the present study via their time implications and their sanding discs. The feasible and potential effectiveness were revealed in this study as decisive factors in structuring primary School Active Break Program, which is able to enhance schooled bodies global mobility with the required standing discs sitting adjustments.

Table 5 - The Pearson correlation between voluntary time standing and classroom static sitting

\begin{tabular}{|c|c|c|c|c|c|}
\hline \multicolumn{2}{|c|}{$\begin{array}{c}\text { Pearson } \\
\text { Correlation }\end{array}$} & 1 Group & 2 Group & 3 Group & 4 Group \\
\hline Day & $0.82^{* *}$ & $-0.76^{* *}$ & $-0.84^{* *}$ & $0.98^{* *}$ \\
\hline Week & \multirow{2}{*}{$=45$} & $0.74^{* *}$ & $-0.72^{* *}$ & $-0.81^{* *}$ & $0.96^{* *}$ \\
\cline { 1 - 5 } Month & $0.78^{* *}$ & $-0.75^{* *}$ & $-0.80^{* *}$ & $0.92^{* *}$ \\
\hline
\end{tabular}

Note: Set at $\mathrm{P} \leq 0.05$ affirmed by SPSS at $0.01{ }^{* *}$.

Discussion. The purpose of the study was to test the effect of frequency and time implications as decisive factors in structuring primary school active break programs (ABC-PA). This study compared previous active break interventions. Claims via their 
time implication support under two subjections, 10 to 20 -min per day versus $3^{*} 5$-min at the classroom [2]. Some modifications were requested regarding the required intensity and frequency of the ACTI-BREAKS to improve fidelity [1].

Our findings highlight all the ABC-PA times and frequencies modalities proposed. The ideal strategies were admitted to promote meaningful classroom bodily activity routine [14], considering the results archived by the control group in the post-test.

Advances in the current study owed to the complimentary time active break followed by our experimental groups, are shown in Figure 2 and Table 2. Fitness-Gram was accommodated as a comprehensive battery of health-related fitness assessments [8], in the interest of all classroom-based, physical activity interventions practised [15]. Time-efficient physical activity strategies are advanced as beneficial and they increase children's daily physical activity during school hours [16]. They should be set in Algerian studies as requested based on practice needs for our primary schools [17].

Krause, et al. propose these methods as strategies to decrease the time children spend in this inactivity setting associated with a wide range of health problems [18], including the decline in functional capacity, and a reduction in skeletal muscle capacity (cardiorespiratory endurance, strength, flexibility, muscular endurance, reaction and movement times, balance) [19].

The limit results achieved by the control group in the post-test were established in the case of our education system. It was explained due to their sitting in their classrooms, which exceeds 6 hours per day.

The Algerian preventive studies documented inactive time in classroom as high risk factor for no communicable diseases strongly related to obesity and overweight among our children [20].

The LSD Post Hoc tests were carried out to identify the effect of frequency and time implications as decisive factors in structuring primary school activities-break programs. Our findings confirmed the judgment of Glapa et al., that frequently active break program, which is $5 \mathrm{~min}$ long, is more effective than those which are longer [6]. Shown by E Sousa-Sá et al. (2020) the number of breaks, with intensifications, increase energy expenditure and interrupting sitting time [21].

This study encouraged the use of 2-minute ABCPA after every 20 minutes per day after static-sitting in the classroom. This model is more satisfactory than other models of increasing the daily physical activity of children during school hours [5]. It was emphasized in this study by the significant inverse correlation between active standing time and inactive chair sitting time in the classroom [22], which was listed in Table 5.
Enabling Algerian primary children to improve their standing desks and it logically reduces their excessive per day sitting time [17] monitored in Figure 2.

Therefore, in accordance with the recommendations of active break programs, we agree that short active breaks (e.g. $<5 \mathrm{~min}$ ) were able to increase children's daily physical activity more during school hours than long ones.

This study recorded the feasibility and potential of a 2-minute ABC-PA repeated repeatedly after each fixed 20-minute session in the classroom.

Physical medicine and rehabilitation studies advocated it as an appropriate time for postural rest to be performed during 2 minutes, after every 20 to $30 \mathrm{~min}$ utes of prolonged static preparation [16]. This study advanced due to its frequency and time appropriate physical activity capable of increasing energy intake and interrupting sitting time $[21,23]$ advocate the replacement of sitting with standing as one of several recommendations to reduce sitting time and increase daily energy intake to prevent long-term weight gain.

Reports across this study demonstrate a positive impact on classroom time standing discs, overall energy expenditure, and cardio-metabolic outcomes [24]. Researchers are allowed to recommend it to Algerian primary schools in all its parts (administration - teachers - parents and students). Application of the short model for no longer than 5 minutes as a prominent strategy are used by teachers to increase children's daily physical activity during school hours [4].

Conclusion. The study is supported by the objective of the study and statistics applied. Our outcomes confirmed that it is better to use the short break program no longer than 5 minutes, frequently repeated with 2 minutes, after every 20 minutes of prolonged static setting. It has to be used as the prominent strategy for structuring the feasible and potential efficacy of primary school Active Break Program. This model was accepted in this study by their total standing disks per day as more satisfactory one than the other models proposed in this study. We considered a potential strategy to reduce sitting time and increase daily energy expenditure in this study.

\section{Acknowledgements}

The results confirmed that total time standing in the classroom is one of several recommendations to structure the feasible and potential efficacy of primary school Active Break Program. This model is able to decrease sedentary time and increase daily energy expenditure

\section{Conflicts of Interest}

The authors declare there is no conflict of interest 


\section{References}

1. Watson A, Timperio A, Brown H, Hesketh KD. Process evaluation of a classroom active break (ACTI-BREAK) program for improving academic-related and physical activity outcomes for students in years 3 and 4 . BMC Public Health. 2019 May 24;19(1):633. PMID: 31126278. PMCID: PMC6533703. doi: 10.1186/s12889-019-6982-z

2. Stapp AC, Prior LF. The Impact of Physically Active Brain Breaks on College Students' Activity Levels and Perceptions. J Physical Activity Res. 2018; 3(1): 60-67. doi: 10.12691/jpar-3-1-10

3. Liu F, Wang W, Ma J, Sa R, Zhuang G. Different associations of sufficient and vigorous physical activity with BMI in Northwest China. Sci Rep. 2018 Sep 3; 8(1): 13120. PMID: 30177717. PMCID: PMC6120905. doi: 10.1038/ s41598-018-31227-6

4. Heneghan RN, Baker G, Thomas K, Falla D, Rushton A. What is the effect of prolonged sitting and physical activity on thoracic spine mobility? An observational study of young adults in a UK university setting. BMJ Open. 2018 May 5; 8(5): e019371. PMID: 29730619. PMCID: PMC5942425. doi: 10.1136/bmjopen-2017-019371

5. Watson A, Timperio A, Brown H, Best K, Hesketh KD. Effect of classroom-based physical activity interventions on academic and physical activity outcomes: A systematic review and meta-analysis. Int J Behav Nutr Phys Act. 2017 Aug 25; 14(1): 114. PMID: 28841890. PMCID: PMC5574081. doi: 10.1186/s12966-017-0569-9

6. Glapa A, Grzesiak J, Laudanska-Krzeminska I, Chin MK, Edginton CR, Mok MMC, et al. The Impact of Brain Breaks Classroom-Based Physical Activities on Attitudes toward Physical Activity in Polish School Children in Third to Fifth Grade. Int J Environ Res Public Health. 2018 Feb 21; 15(2): 368. PMID: 29466285. PMCID: PMC5858437. doi: 10.3390/ijerph15020368

7. Kohl HW III., Murray TD, Salvo D. Foundations of physical activity and public health. Champaign, IL: Human Kinetics; 2020.

8. Cooper Institute for Aerobics Research. FitnessGram administration manual: the journey to MyHealthyZone. Champaign, IL: Human Kinetics; 2017.

9. National Academy of Sports Medicine. NASM essentials of personal fitness training. Philadelphia USA: Lippincott Williams \& Wilkins; 2008.

10. Cooper KH, Greenberg JD, Castelli DM, Barton M, Martin SB, Morrow JR Jr. Implementing Policies to Enhance Physical Education and Physical Activity in Schools. Res Q Exerc Sport. 2016 Jun;87(2):133-40. PMID: 27100264. doi: 10.1080/02701367.2016.1164009

11. Graham DJ, Hipp JA. Emerging Technologies to Promote and Evaluate Physical Activity: cutting-edge research and future directions. Front Public Health. 2014 Jun 27; 2: 66. PMID: 25019066. doi: 10.3389/fpubh.2014.00066

12. Hills AP, Dengel DR, Lubans DR. Supporting public health priorities: Recommendations for physical education and physical activity promotion in schools. Prog Cardiovasc Dis. 2015 Jan-Feb; 57(4): 368-74. PMID: 25269062. doi: 10.1016/j.pcad.2014.09.010

13. Masanovic B, Milosevic Z, Bjelica D. Comparative study of anthropometric measurement and body composition between soccer players from different competitive levels, elite and sub-elite. Pedagogics, psychology, medical-biological problems of physical training and sports. 2019; 23(6): 282-7. doi: 10.15561/18189172.2019.0602

14. Chin MK, Edginton CR, Tang MS. School physical education and health: A model of best practice, integrating local context with global trends. Glob J Health Phys Educ Pedagog. 2012; 1: 251-282.

15. Aparicio VA, Soriano-Maldonado A, Buitrago F, Félix-Redondo FJ, Fernández-Bergés D. The Role of Sex and Domestic Physical Activity on the Metabolically Healthy and Unhealthy Obesity. The HERMEX Study. Rev Esp Cardiol (Engl Ed). 2016 Oct; 69(10): 983-986. PMID: 27453252. doi: 10.1016/j.rec.2016.04.050

16. Cassidy JT, Petty RE, Laxer R, Lindsley C. Textbook of pediatric rheumatology. Philadelphia, PA: Saunders; 2011.

17. Zerf M. Breaks in primary schools and their influence on maintaining and promoting physical fitness and wellness at the level of middle schools. Timisoara Physical Education \& Rehabilitation Journal. 2018; 11(21): 7-12. doi: 10.2478/tperj-2018-0010

18. Krause JM, Benavidez EA. Potential influences of exergaming on self-efficacy for physical activity and sport. $J$ Phys Educ Recreat Dance. 2014; 85: 15-20. doi: 10.1080/07303084.2014.884428

19. Türk Y, Theel W, Kasteleyn MJ, Franssen FME, Hiemstra PS, Rudolphus A, et al. High-intensity training in obesity: a meta-analysis. Obes Sci Pract. 2017; 3(3): 258-271. PMID: 29071102. PMCID: PMC5598019. doi: 10.1002/osp4.109

20. Zerf M. Dance-based body-movement as kinesthetic therapy to reduce the impact of Prolonged Periods Classroom Settings Algerian Primary School. World News of Natural Sciences. 2019; 23: 56-68.

21. Sousa-Sá E, McNeill J, Pereira JR, Zhang Z, Okely AD, Santos R. Systematic Review on the Associations between Objectively Measured Breaks in Sitting Time and Cardiovascular Health in Youth. Int $J$ Phys Edu Fitness Sports. 2020; 1:26-43. doi: 10.34256/ijpefs2013

22. Le Masurier GC, Corbin CB, Baker K, Byl J. Fitness for life Canada: preparing teens for healthy, active lifestyles. Champaign, IL: Human Kinetics; 2017. 
23. Saeidifard F, Medina-Inojosa JR, Supervia M, Olson TP, Somers VK, Erwin PJ, et al. Differences of energy expenditure while sitting versus standing: A systematic review and meta-analysis. Eur J Prev Cardiol. 2018; 25(5): 522-538. PMID: 29385357. doi: 10.1177/2047487317752186

24. Mantzari E, Galloway C, Wijndaele K, Brage S, Griffin SJ, Marteau TM. Impact of sit-stand desks at work on energy expenditure, sitting time and cardio-metabolic risk factors: Multiphase feasibility study with randomised controlled component. Prev Med Rep. 2018 Nov 26; 13: 64-72. PMID: 31304079. PMCID: PMC6603239. doi: 10.1016/j.pmedr.2018.11.012

Удк 613.72:373.3.09]=111

\section{ВПЛИВ ЧАСТОТИ ТА ТРИВАЛОСТІ НА ЕФЕКТИВНІСТЬ} ПРОГРАМ АКТИВНИХ ПЕРЕРВ У ПОЧАТКОВІЙ ШКОЛІ

\section{Зерф Мохаммед, Абделькадер Геблі, Мохамед Хаджар Херфане}

Резюме. Метою дослідження було дослідити вплив частоти та тривалості активних перерв на ефрективність програм активних перерв у початковій школі.

Матеріали та методи. Це дослідження було визнано першим алжирським пілотним проектом серед початкових шкіл. Його призначення мало на меті перевірити вплив наслідків частоти та тривалості як вирішальних фракторів у побудові програм активних перерв у початковій школі.

У дослідженні брали участь 4 вчителі та 5 класів. Усього дослідження охоплювало 180 дітей (100 ді-

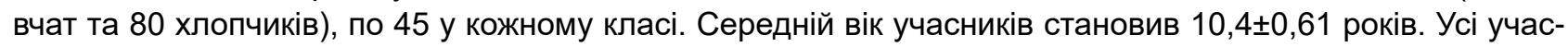
ники надали письмову згоду на участь у дослідженні. Комітет з етики Інституту фрізичного виховання Університету Абдель Хаміда Ібн Бадіса Мостаганема також схвалив його.

Усі діти були поділені на чотири групи. Учні з Групи 1 (20 хлопчиків та 25 дівчаток) після кожних 20 хвилин сидіння за партою виконували вправи упродовж двох хвилин. У Групі 2 (19 хлопчиків та 26 дівчаток) вправи виконували упродовж шести хвилин після кожної години сидіння. У Групі 3 (19 хлопчиків та 26 дівчаток) застосовували 9-хвилинну традиційну програму активних перерв у класі, інтегровану до звичайних шкільних програм. Група 4 була контрольною і не мала програми фрізичної активності на основі активних перерв у класі. Усіх учителів, які добровільно погодилися взяти участь в дослідженні, попросили використовувати відеозаписи для учнів, відповідно до моделі та змісту (час-тривалість), і заохочувати своїх учнів щоденно повторювати запропоновані базові фізичні вправи. До програми фрізичної активності було включено такі вправи: віджимання, тягу, присідання, підйоми зі стільця на одній нозі, вправи на гнучкість, міофасціальний реліз та статичний стретчінг

Результати і обговорення. У цьому дослідженні зосереджено увагу на трьох варіантах частоти і тривалості запропонованих фрізичних вправ під час активних перерв. Проведене дослідження підтвердило переваги програми коротких активних перерв у класах. Вищі показники, ніж у контрольній групі, були зафіксовані у тестах після запровадження відповідних програм. Дане дослідження пояснює це додатковим часом, який використовували в експериментальних групах відповідно до програми фізичної активності на основі активних перерв у класі. Були встановлені достовірно значущі зворотні кореляційні зв'язки між активним часом стояння та неактивним часом сидіння на кріслі.

Висновок. Результати дослідження підтвердили, що корисніше використовувати короткотривалу програму активної перерви не довше 5 хвилин, з частотою повторень через 2 хвилини, після кожних 20 хвилин перебування у статичному положенні. Цю модель слід використовувати як головну стратегію для побудови можливої та потенційної ефективності програми активних перерв у початковій школі. Вона здатна скоротити час сидіння за партою та збільшити щоденні витрати енергії.

Ключові слова: початкові школи, діти, фізична активність, тривалість і частота вправ, програма активних перерв.

УдК 613.72: 373.3.09] = 111

ВЛИЯНИЕ ЧАСТОТЫ И ПРОДОЛЖИТЕЛЬНОСТИ

НА ЭФФЕКТИВНОСТЬ ПРОГРАММ АКТИВНЫХ ПЕРЕРЫВОВ В НАЧАЛЬНОЙ ШКОЛЕ

Зерф Мохаммед, Абделькадер Гебли, Мохамед Хаджар Херфане

Резюме. Целью исследования было изучить влияние частоты и длительности активных перерывов на эффективность программ активных перерывов в начальной школе.

Материалы и методы. Это исследование было признано первым алжирским пилотным проектом среди начальных школ. Его целью было проверить влияние последствий частоты и продолжительности как решающих фракторов в построении программ активных перерывов в начальной школе.

В исследовании принимали участие 4 учителя и 5 классов. Всего исследование охватывало 180 детей (100 девочек и 80 мальчиков), по 45 в каждом классе. Средний возраст участников составил 
10,4 \pm ,61 лет. Все участники предоставили письменное согласие на участие в исследовании. Комитет по этике Института фризического воспитания Университета Абдель Хамида Ибн Бадиса Мостаганема также одобрил его.

Все дети были разделены на четыре группы. Ученики из группы 1 (20 мальчиков и 25 девочек) после каждых 20 минут сидения за партой выполняли упражнения в течение двух минут. В группе 2 (19 мальчиков и 26 девочек) упражнения выполняли в течение шести минут после каждого часа сидения. В группе 3 (19 мальчиков и 26 девочек) применяли 9-минутную традиционную программу активных перерывов в классе, интегрированную в обычных школьных программах. Группа 4 была контрольной, и не имела программы физической активности на основе активных перерывов в классе. Всех учителей, добровольно согласившихся принять участие в исследовании, попросили использовать видеозаписи для учащихся, согласно модели и содержания (время продолжительность), и поощрять своих учеников ежедневно повторять предложенные базовые физические упражнения. В программу физической активности были включены следующие упражнения: отжимания, тяга, приседания, подъемы со стула на одной ноге, упражнения на гибкость, миофасциальный релиз и статический стретчинг.

Результаты и обсуждение. Данное исследование сосредоточено на трех вариантах частоты и продолжительности предложенных физических упражнений во время активных перемен. Проведенное исследование подтвердило преимущества программы коротких активных перерывов в классах. Более высокие показатели, чем в контрольной группе, были зафиксированы в тестах после введения соответствующих программ. Данное исследование объясняет это дополнительным временем, которое использовали в экспериментальных группах в соответствии с программой фризической активности на основе активных перерывов в классе. Были установлены достоверно значимые обратные корреляционные связи между активным временем стояния и неактивным время сидения на кресле.

Выводы. Результаты исследования подтвердили, что полезнее использовать кратковременную программу активной перерыва не более 5 минут, с частотой повторений через 2 минуты, после каждых 20 минут пребывания в статическом положении. Эту модель следует использовать как главную стратегию для построения возможной и потенциальной эффрективности программы активных перерывов в начальной школе. Она способна сократить время сидения за партой и увеличить ежедневные расходы энергии.

Ключевые слова: начальные школы, дети, фризическая активность, продолжительность и частота упражнений, программа активных перерывов.

ORCID and contributionship:

Zerf Mohammed : 0000-0001-5013-5446 A,B,C,D,E,F

Abdelkader Guebli : 0000-0001-5314-4903 A,B,C,D,E,F

Mohamed Hadjar Kherfane : 0000-0003-3353-6154 A,B,C,D,E,F

A - Work concept and design, B - Data collection and analysis,

C - Responsibility for statistical analysis, D - Writing the article,

$\mathrm{E}$ - Critical review, F - Final approval of the article

\section{CORRESPONDING AUTHOR}

Zerf Mohammed

Abdel Hamid Ibn Badis University Mostaganem Institute of Physical Education and Sports

BP 227 St., Mostaganem 27000, Algeria

tel: 213773450124, e-mail: biomeca.zerf@outlook.com

The authors of this study confirm that the research and publication of the results were not associated with any conflicts regarding commercial or financial relations, relations with organizations and/or individuals who may have been related to the study, and interrelations of coauthors of the article.

Стаття надійшла 23.08.2021 р.

Рекомендована до друку на засіданні редакційної колегії після рецензування 